DOI: $10.19195 / 2084-5065.39 .3$

\title{
Kwestia dopuszczalności stosowania środków zabezpieczających w stosunku do nieletnich sprawców czynów karalnych. Część II
}

\author{
PIOTR GÓRALSKI \\ Katedra Prawa Karnego Materialnego Uniwersytetu Wrocławskiego \\ Wydział Prawa, Administracji i Ekonomii
}

\section{Zasady stosowania środków zabezpieczających wobec nieletnich przestępców na podstawie przepisów kodeksu karnego w latach 1997-2015}

Sytuacja w zakresie stosowania środków zabezpieczających (zwanych też środkami ochronnymi) względem nieletnich sprawców czynów karalnych uległa komplikacji wraz z wejściem w życie przepisów k.k. z 1997 r. ${ }^{1}$ Ustawa ta obniżyła bowiem wiek odpowiedzialności karnej nieletnich za dokonanie przestępstw przewidzianych w art. $10 \S 2$ k.k. do granicy 15 roku życia, zwiększono też w porównaniu z poprzednią regulacją zakres czynów zabronionych, za które nieletni może podlegać odpowiedzialności karnej. Za stałą już chyba tendencję (choć na szczęście w ostatnich latach zarzucona) można uznać wysuwanie propozycji rozszerzenia zasad odpowiedzialności karnej nieletnich ${ }^{2}$ oraz dalszego obniżenia wieku odpowie-

1 Ustawa z dnia 6 czerwca 1997 r. Kodeks karny, Dz.U. z 1997 r. Nr 88, poz. 553.

2 Por. założenia projektu ustawy Kodeks nieletnich z dnia 21 lutego 2007 r. oraz projektu nowelizacji ustawy Kodeks karny z dnia 22 maja 2007 r.

Nowa Kodyfikacja Prawa Karnego 39, 2016

(C) for this edition by CNS 
dzialności karnej tej kategorii osób ${ }^{3}$. Jednocześnie w art. 93 k.k. pojawiła się zasada — nieznana dwóm poprzednim kodyfikacjom karnym — ograniczająca zastosowanie izolacyjnych środków zabezpieczających tylko do niezbędnych przypadków. W tym momencie musiało się nasunąć pytanie, czy do nieletnich — dzieci cierpiących na różnego rodzaju schorzenia psy-

Wskazany projekt Kodeksu nieletnich zakładał m.in. znaczne rozszerzenie zakresu czynów, za które nieletni mogli by ponosić odpowiedzialność karną na podstawie art. 10 $\S 2$ k.k. Przewidywał też możliwość umieszczenia nieletniego w zakładzie poprawczym do 18 roku życia, a następnie jego przeniesienie do zakładu karnego, jeżeli ów nieletni dopuścił się umyślnego przestępstwa, będąc już uprzednio umieszczonym w zakładzie poprawczym. Taką możliwość przewidywano nawet w stosunku do nieletnich, którzy w chwili czynu karalnego ukończyli lat 13. Zob. szerzej na ten temat V. Konarska-Wrzosek, Zakład poprawczy czy zakład karny dla nieletnich, [w:] Pozbawienie wolności funkcje i koszty. Księga jubileuszowa prof. T. Szymanowskiego, red. I. Rzeplińska et al., Warszawa 2013, s. 891.

Z kolei w projekcie nowelizacji kodeksu karnego z dnia 22 maja 2007 r. przewidywano możliwość karania nieletnich w wieku 15 lat za wszystkie przewidziane w prawie karnym zbrodnie i taksatywnie wymienione w projekcie występki. Według nowego art. $10 \S 2 \mathrm{a}$ k.k. proponowanego przez autorów projektu, jeżeli nieletni przebywał już wcześniej w zakładzie karnym lub w zakładzie poprawczym i ponownie dopuścił się czynu z art. $10 \S 2$ k.k., wówczas sąd miałby obowiązek wymierzyć mu karę przewidzianą w tym przepisie. Zasadnicze założenia tego projektu zostały omówione w artykule O. Rataj, Projektowane zmiany w zakresie odpowiedzialności karnej nieletnich $w$ kodeksie karnym, „Prokuratura i Prawo” 2008, nr 1, s. 126-127.

3 W doktrynie coraz częściej reprezentowane jest stanowisko, że zasadniczy wiek odpowiedzialności karnej powinien zostać podwyższony do lat 18, tak aby zrównać go z terminalną granicą rozwojową odpowiedzialności w obszarze prawa cywilnego, jak również uczynić zadość postanowieniom Konwencji o prawach dziecka przewidującej taki właśnie okres małoletniości w każdej dziedzinie prawa (zob. Konwencja o prawach dziecka przyjęta przez Zgromadzenie Ogólne Narodów Zjednoczonych w dniu 20 listopada 1989 r., ratyfikowana zaś przez Polskę w dniu 30 kwietnia 1991 r. (Dz.U. z 1991 r. $\mathrm{Nr}$ 120, poz. 526). Jednocześnie, co wydaje się niezrozumiałe, nawet zwolennicy podwyższenia granicy wieku zasadniczej odpowiedzialności karnej do lat 18 opowiadają się niekiedy za możliwością dalszego obniżenia wyjątkowej odpowiedzialności, w wypadkach obecnie przewidzianych w art. $10 \S 2$ k.k., nawet do 14 roku życia (zob. M. Lubelski, O pilnej potrzebie podniesienia granicy wieku odpowiedzialności karnej, „Archiwum Kryminologii”, t. XXIX-XXX, 2007-2008, s. 381). A przecież trzeba mieć świadomość, że przyjęcie takich unormowań w stosunku do dzieci w wieku lat 14 musiałoby prawdopodobnie pociagnąć za sobą także stosowanie do nich środków zabezpieczających. Wydaje się, że kwestia ta w ogóle nie jest dostrzegana obecnie w doktrynie polskiego prawa karnego. 
chiczne i (lub) dotkniętych upośledzeniem umysłowym bądź uzależnionych od środków odurzających, względnie od alkoholu, które podlegałyby odpowiedzialności na zasadzie art. $10 \S 2$ k.k., powinno się stosować środki zabezpieczające, czy też — skoro izolacyjne środki zabezpieczające należy wdrażać tylko w niezbędnych przypadkach, wobec sprawców najcięższych przestępstw popełnianych przez niebezpieczne osoby dorosłe - to w sprawach nieletnich sprawców, wymagających zróżnicowanych form leczenia, można by poprzestać na stosowaniu środków wychowawczych, wychowawczo-leczniczych, względnie środka poprawczego, przewidzianych $\mathrm{w}$ ustawie o postępowaniu $\mathrm{w}$ sprawach nieletnich ${ }^{4}$ (dalej cyt. jako u.p.n.) $)^{5}$. Widać bowiem podobieństwo pomiędzy przewidzianymi w u.p.n. środkami wychowawczymi a tzw. administracyjnymi środkami zabezpieczającymi ${ }^{6}$ oraz pomiędzy środkami wychowawczo-leczniczymi a środkami zabezpieczającymi o charakterze izolacyjno-leczniczym ${ }^{7}$. Do środków wychowawczych przewidzianych w u.p.n., które pod względem realizowanych funkcji odpowiadają środkom zabezpieczającym orzeka-

${ }^{4}$ Ustawa o postępowaniu w sprawach nieletnich z dnia 26 października 1982 r., Dz.U. z. 1982 r. Nr 35, poz. 22.

5 Jednym z argumentów przemawiających za dopuszczalnością stosowania środków zabezpieczających względem nieletnich przestępców może być konieczność położenia obecnie zwiększonego nacisku na funkcję ochrony społeczeństwa przed agresywnymi zachowaniami osób nieletnich stosujących coraz częściej przemoc wobec ofiar swych czynów. Badania wskazują, że w przeciwieństwie do okresu lat osiemdziesiątych ubiegłego wieku, gdy dominowały przestępstwa przeciwko mieniu w postaci kradzieży i kradzieży z włamaniem, od połowy lat dziewięćdziesiątych ubiegłego wieku zaczęła narastać przestępczość nieletnich $\mathrm{w}$ formie czynów skierowanych przeciwko życiu i zdrowiu oraz karalnych zachowań z użyciem przemocy przeciwko osobie. Zob. I. Rzep-lińska, Nieletni oraz reakcja na ich czyn, [w:] Nauki penalne wobec szybkich przemian socjokulturowych, Księga jubileuszowa prof. M. Filara, red. A. Adamski et. al., t. I, Toruń 2012, s. 531.

${ }^{6}$ To podobieństwo treściowe do środków zabezpieczających skłania nawet niektórych przedstawicieli doktryny do wyodrębnienia przepadku oraz zakazu prowadzenia pojazdów na tle pozostałych środków wychowawczych zawartych w ustawie o nieletnich i zaliczenia ich do oddzielnej grupy środków wychowawczo-restrykcyjnych spełniających głównie cele zapobiegawcze. Tak czyni np. E. Filipkowska - zob. Postępowanie w sprawach nieletnich, Warszawa 2003, s. 45, s. 61.

${ }^{7}$ K. Eichstaedt, Postępowanie przed sqdem w sprawach nieletnich, Warszawa 2008, s. 50,58 . 
nym w stosunku do sprawców odpowiadających na zasadach przewidzianych w kodeksie karnym, można zaliczyć:

- zobowiązanie nieletniego przez sąd rodzinny do określonego postępowania, a zwłaszcza do uczestniczenia w odpowiednich zajęciach o charakterze terapeutycznym, powstrzymania się od przebywania w określonych środowiskach lub miejscach, jak również zaniechania używania alkoholu lub innego środka w celu wprowadzenia się w stan odurzenia (art. 6 pkt 2 u.p.n.). Ta ogólnie określona klauzula otwiera możliwość orzeczenia przez sąd rodzinny w charakterze środka wychowawczego także innych, niewymienionych wprost w art. 6 u.p.n., różnorodnych obowiązków odpowiadających zakresowi zakazów wskazanych w art. 39 pkt 2-3 w zw. z art. 99 k.k. $§ 1$ k.k. Chodziłoby tu np. o zakaz wstępu na imprezę masową, zakaz kontaktowania się z określonymi osobami (np. należącymi do szkodliwych sekt religijnych) czy zakaz wstępu do ośrodków gier ${ }^{8}$;

— skierowanie do organizacji społecznej lub instytucji zajmujących się pracą z nieletnimi o charakterze terapeutycznym, po uprzednim porozumieniu się z tą organizacją lub instytucją (art. 6 pkt 6 u.p.n.);

— orzeczenie zakazu prowadzenia pojazdów (art. 6 pkt 7 u.p.n.);

- orzeczenie przepadku rzeczy uzyskanych w związku z popełnieniem czynu karalnego (art. 6 pkt 8 u.p.n.).

Ponadto zgodnie $\mathrm{z}$ treścią art. 12 u.p.n. w razie stwierdzenia u nieletniego upośledzenia umysłowego, choroby psychicznej lub innego zakłócenia czynności psychicznych bądź nałogowego używania alkoholu albo innych środków w celu wprowadzenia się w stan odurzenia sąd rodzinny może orzec umieszczenie nieletniego w szpitalu psychiatrycznym lub innym odpowiednim zakładzie leczniczym. Jeżeli zachodzi potrzeba zapewnienia nieletniemu jedynie opieki wychowawczej, sąd może orzec umieszczenie go w młodzieżowym ośrodku wychowawczym, a w przypadku gdy nieletni jest upośledzony w stopniu głębokim i wymaga jedynie opieki — w domu pomocy społecznej.

Z kolei wyjątkowo zdemoralizowanych nieletnich sprawców przestępstw oraz przestępstw skarbowych, zwłaszcza gdy inne środki wychowawcze okazały się nieskuteczne lub nie rokują resocjalizacji takich

8 V. Konarska-Wrzosek, Prawny system postepowania z nieletnimi w Polsce, Warszawa 2013, s. 83-84; K. Eichstaedt, op. cit., s. 46; T. Bojarski, E. Skrętowicz, Ustawa o postępowaniu w sprawach nieletnich. Komentarz, Warszawa 2011, s. 61. 
osób, sąd rodzinny może umieścić w zakładzie poprawczym (art. 6 pkt 10 u.p.n. w zw. $z$ art. 10 u.p.n.).

Przechodząc do omówienia kwestii stosowania środków zabezpieczających $\mathrm{w}$ stosunku do nieletnich odpowiadających na podstawie art. 10 § 2 k.k., należy zauważyć, że w treści k.k. z 1997 r. pojawiły się dwa środki zabezpieczające, nieznane wcześniejszym uregulowaniom kodyfikacyjnym, których realizacja względem nieletnich przestępców odpowiadających karnie na podstawie art. $10 \S 2$ k.k. musiała wzbudzać wątpliwości, uwzględniając istnienie zasady humanitaryzmu stosowania sankcji karnych określonej w art. 3 k.k. Pierwszy z nich zawarty został w art. 95 k.k. i przewidywał wykonywanie izolacyjno-leczniczego środka zabezpieczającego w zakładzie karnym w stosunku do przestępców, którzy dopuścili się czynów zabronionych w stanie poczytalności ograniczonej w stopniu znacznym. W praktyce istnienie tego przepisu w połączeniu z treścią art. $10 \S 2$ k.k. umożliwiało kierowanie do zakładów karnych piętnasto- i szesnastoletnich przestępców upośledzonych umysłowo (także w stopniu znacznym, a nawet w stopniu głębokim), jeśli tylko zostałaby stwierdzona ich poczytalność w chwili dokonania czynu zabronionego. Rozwiązanie to było wadliwe zarówno pod względem teoretycznym, jak i w zakresie praktycznych jego konsekwencji. Trudno tu było mówić o środku zabezpieczającym, skoro art. 95 k.k. przewidywał właściwie specyficzny tryb wykonywania kary pozbawienia wolności. Poza tym, jeśli można wyrażać zastrzeżenia co do celowości i humanitarności umieszczania w zakładach karnych dorosłych przestępców niedorozwiniętych umysłowo, to kierowanie tam osłabionych intelektualnie dzieci w wieku 15-16 lat musiało budzić kategoryczny sprzeciw.

Również stosowanie wobec nieletnich przestępców środka zabezpieczającego przewidzianego w treści art. 95a k.k. pozostawałoby w sprzeczności z celami stawianymi tej instytucji. Przepis ten przewidywał bowiem postpenalny środek ochronny realizowany w stosunku do przestępców wykazujących zaburzenia preferencji seksualnych w razie nieskuteczności orzekanych wcześniej wobec takich osób kar, a zwłaszcza kary pozbawienia wolności ${ }^{9}$. Środek ten był bowiem orzekany przez sąd wyłącznie

9 Należy w tym miejscu zwrócić uwagę, że dzieci nawet już w wieku 11 lat mogą się dopuszczać poważnych przestępstw będących wynikiem zaburzeń seksualnych powstałych w tak wczesnym okresie życia. Zaburzenia seksualne — takie jak np. pedofilia czy 
w razie skazania sprawcy na bezwzględną karę pozbawienia wolności, przy czym przed zakończeniem jej wykonania sąd sprawdzał, czy realizacja orzeczonego wcześniej środka zabezpieczającego była w dalszym ciągu konieczna, czy też nie. Chodziło zatem w tym wypadku o przestępców wykazujących utrwalone skłonności dewiacyjne w zakresie życia seksualnego, wobec których izolacja postpenalna w połączeniu z leczeniem farmakologicznym i psychoterapią miała stanowić ostateczny środek ochrony społeczeństwa. W przypadku nieletnich odpowiadających karnie nie można jednak jeszcze mówić ani o zakończonym procesie kształtowania się osobowości (stąd istnieje poważne ryzyko pomyłki w ustalaniu wystąpienia w tak młodym wieku zaburzeń seksualnych), ani też o trwałym już wejściu tych osób na drogę stałego naruszania prawa, a w związku z tym o niemożliwości lub niecelowości działań terapeutycznych i wychowawczych podejmowanych za pomocą innych sposobów i środków niż sankcje prawa karnego, a w szczególności środki zabezpieczające.

Mogłoby się wydawać, że spośród środków zabezpieczających przewidzianych w pierwotnej wersji k.k. z 1997 r. najbardziej uzasadnione, bo głęboko nasycone czynnikiem terapeutycznym, wydawało się stosowanie do niepoczytalnych nieletnich odpowiadających karnie internacji w zakładzie psychiatrycznym (art. 94 k.k.) ${ }^{10}$. Jednakże dopuszczalność umieszczania niepoczytalnych w chwili czynu, nieletnich sprawców zachowań karalnych w zakładach psychiatrycznych na zasadzie środka zabezpieczającego nie miała - jak można sądzić - bezwzględnego poparcia w poglądach doktryny. Jej przedstawiciele — specjalizujący się zresztą w prawie nieletnich — niejednokrotnie opowiadali się przeciwko odpowiedzialności nieletnich chorych psychicznie i upośledzonych umy-

gerontofilia - mogą rozwijać się w dzieciństwie i w okresie dojrzewania. Dziesiąta rewizja Międzynarodowej Klasyfikacji Chorób, Urazów i Przyczyn Zgonów (ICD - 10) definiuje pedofilię jako zaburzenie właściwe dla osób w wieku co najmniej 16 lat. Cyt. za Z. Lew-Starowicz, Seksuologia sqdowa, Warszawa 2000, s. 126, 144-145, 250.

10 Pomimo tego że większość psychoz występuje i rozwija się u osób dorosłych, to w okresie dojrzewania mogą się już ujawniać niektóre z nich, stanowiąc przy tym podłoże popełnienia czynu karalnego przez nieletniego dotkniętego ich objawami. Przykładowo schizofrenia, zwłaszcza u mężczyzn, może się pojawić nawet w 15 roku ży c i a, to samo dotyczy depresji. Zob. A. Bilikiewicz, J. Landowski, P. Radziwiłowicz, Psychiatria, Warszawa 1999, s. 51, 73; por. K. de Walden-Gałuszko, Zarys psychopatologii ogólnej i psychiatrii, Gdańsk 1999, s. 61-65. 
słowo na podstawie art. $10 \S 2$ k.k. ${ }^{11}$ Takie stanowisko oznaczało, że skoro nie powinno się do tej kategorii nieletnich odnosić zasad odpowiedzialności karnej, to tym samym niedopuszczalna byłaby realizacja wobec takich osób środka zabezpieczającego przewidzianego w treści art. 94 k.k.

W zakresie wdrażania wobec piętnasto- i szesnastoletnich przestępców odpowiadających karnie na podstawie art. $10 \S 2$ k.k. pozostałych środków zabezpieczających nie formułowano w doktrynie zastrzeżeń. Podobnie było na gruncie judykatury, przy czym odnotować tu należy poparcie orzecznictwa sądowego dla dopuszczalności orzekania wobec nieletnich środka zabezpieczającego w postaci przepadku na podstawie art. 100 k.k. Mianowicie w uchwale z dnia 13 stycznia 2005 r. ${ }^{12}$ Sąd Najwyższy przyjął, że w przypadku nieletniego, który nie odpowiada karnie za popełnioną kradzież z włamaniem, lecz znajdują do niego zastosowanie przewidziane $\mathrm{w}$ ustawie o postępowaniu w sprawach nieletnich środki wychowawcze, sąd rodzinny stwierdzając niecelowość orzeczenia tychże środków wychowawczych (np. gdy zostały już one podjęte w innej sprawie) może zastosować środek zabezpieczający w postaci przepadku narzędzi przestępstwa na podstawie art. 100 k.k. W treści cytowanej uchwały przyjęto, że u.p.n. nie kształtuje postępowania z nieletnimi w sposób samodzielny i wyczerpujący, ponieważ w kwestiach w niej nieuregulowanych przewidziano odesłania do innych ustaw, a w szczególności do kodeksu karnego (art. 14 u.p.n.). Rozważając wskazaną kwestię, należy stwierdzić, że treść wymienionej uchwały Sądu Najwyższego podzieliła przedstawicieli nauki prawa karnego. Część zaakceptowała zawarte w niej tezy, część natomiast poddała je uzasadnionej krytyce ${ }^{13}$.

11 A. Grześkowiak, Komentarz do rozdziału I k.k. - Zasady odpowiedzialności karnej, [w:] Kodeks karny. Komentarz, red. A. Grześkowiak, K. Wiak, Warszawa 2012 s. 108; V. Konarska-Wrzosek, Prawny system postępowania..., Warszawa 2013, s. 124.

12 Uchwała Sądu Najwyższego z dnia 13 stycznia 2005 r., III CZP 70/04, OSNC $2005 \mathrm{nr}$ 12, poz. 199.

13 Por. akceptujące stanowisko w tej kwestii: P. Górecki, S. Stachowiak, Ustawa o postępowaniu w sprawach nieletnich. Komentarz, Kraków 2005, s. 42; V. Konarska-Wrzosek, Prawny system postępowania..., s. 95-96; A. Witkowska-Płóciennik, Postępowanie w sprawach nieletnich, Warszawa 2011, s. 58-59.

Stanowisko krytyczne wobec przywołanej uchwały Sądu Najwyższego zostało wyrażone m.in. w Komentarzu do u.p.n. autorstwa T. Bojarskiego i E. Skrętowicza (wyd. Warszawa 2011, s. 68) oraz w glosie do tejże uchwały opublikowanej przez M. Siwka 
Główny punkt polemiki ze stanowiskiem wyrażonym przez najwyższą instancję sądową w wymienionym tu judykacie sprowadza się do tego, że za pomocą konstrukcji środka zabezpieczającego w formie przepadku próbuje się faktycznie naprawić niefortunne ujęcie przepadku przyjmującego postać środka wychowawczego. Zgodnie z treścią art. 6 ust. 8 u.p.n. sąd rodzinny został uprawniony do zastosowania w charakterze środka wychowawczego przepadku rzeczy uzyskanych w związku z popełnieniem czynu karalnego. Tak ujęty środek wychowawczy dotyczy zatem bardzo wąsko określonego zakresu rzeczy, mianowicie wyłącznie „owoców przestępstwa" i nie odnosi się m.in. do przedmiotów służących lub przeznaczonych do jego popełnienia ${ }^{14}$. Słusznie zauważa M. Siwek, że stosowanie przepadku instrumenta sceleris w charakterze środka zabezpieczającego $\mathrm{z}$ art. $100 \mathrm{k}$.k. w celu pozbawienia nieletniego użytych przez niego narzędzi czynu karalnego stanowi obejście postanowień u.p.n., które nie przewidują obecnie (chociaż zapewne powinny) takiej postaci przepadku realizowanego w formie środka wychowawczego ${ }^{15}$. Wątpliwe jest także, aby można było potraktować, jak uczynił to Sąd Najwyższy w przedmiotowej uchwale - w charakterze „okoliczności wyłączającej karalność czynu” — decyzję sądu o nie wszczynaniu postępowania opiekuńczo-wychowawczego względem nieletniego. W doktrynie ukształtowany i ustabilizowany jest bowiem pogląd wskazujący, że każdy środek zabezpieczający może zostać orzeczony wyłącznie względem konkretnie wskazanego, żyjącego oskarżonego, w związku z uprzednim wszczęciem wobec niego postępowania karnego ${ }^{16}$.

Akceptując teze, iż stanowisko Sądu Najwyższego zawarte w uchwale z dnia 13 stycznia 2005 r. nie jest przekonujące, należy zarazem dodać, że nie powinno ono również stanowić podstawy do wysnuwania jakichkolwiek argumentów w zakresie stosowania do nieodpowiedzialnych kar-

(zob. „Przegląd Sądowy” 2007, nr 1, s. 114-118 ). Por. też M. Siwek, Materialnoprawne podstawy orzekania środków zabezpieczajacych o charakterze administracyjnym, [w:] System prawa karnego, t. 7 - Środki zabezpieczajace, red. L.K. Paprzycki, Warszawa 2012, s 428-430.

14 M. Siwek, Glosa do uchwały Sadu Najwyższego z dnia 13 stycznia 2005 r., s. 117.

15 Ibidem, s. 117-118.

16 Ibidem, s. 114-116. 
nie nieletnich (tzn. odpowiadających na zasadach określonych w u.p.n.), innych niż przepadek narzędzi czynu karalnego, środków zabezpieczających. Uwagę tę należy odnieść zwłaszcza do instytucji wymierzenia nieletniemu kary na podstawie art. 94 u.p.n. Przepis ten dotyczy sytuacji, w której nieletni dopuścił się czynu karalnego o znamionach przestępstwa, w następstwie czego sąd orzekł wobec niego umieszczenie w zakładzie poprawczym, jednakże — z różnych możliwych przyczyn orzeczenie to nie zostało wykonane. Wówczas, jeżeli nieletni ukończył po wydaniu takiego orzeczenia 18 lat, sąd rodzinny może zdecydować, czy wykonać orzeczony środek poprawczy, czy też od jego wykonania odstapić i wymierzyć takiej osobie karę pozbawienia wolności, obligatoryjnie ją przy tym łagodząc. Zarówno w doktrynie, jak i w orzecznictwie przyjmuje się, że nie może być tu mowy o skazaniu nieletniego ${ }^{17}$. To zaś oznacza, że w niektórych sytuacjach, gdy nieletni odpowiada karnie tj. na podstawie art. $10 \S 2$ k.k. — można by stosować wobec niego środki zabezpieczające, w innym natomiast przypadku takiej odpowiedzialności — statuowanej właśnie przez art. 94 u.p.n. — wdrożenie środków zabezpieczających łączących się ze skazaniem, a więc określonych w treści art. 93 c pkt 2-5 k.k., jest niedopuszczalne ${ }^{18}$.

17 M. Korcyl-Wolska, Postępowanie w sprawach nieletnich, Warszawa 2008, s. 82. Zob. też uchwałę Sądu Najwyższego z dnia 24 kwietnia 1985 r., VI KZP 1/85, OSNKW 1985, nr 7-8, poz. 52.

Przyjmuje się, że nie chodzi tu o potępienie nieletniego wyrokiem sądowym, co jest sensem skazania, lecz o zamianę wykonywania środka poprawczego na karę w zakładzie karnym. Dlatego też pobyt w nim, w tej sytuacji, nie może trwać dłużej niż do ukończenia przez taką osobę 21. roku życia.

18 Do niedawna art. 13 u.p.n. przewidywał jeszcze jedną podstawę prawną wymierzenia kary nieletniemu sprawcy przestępstwa. Mianowicie, jeżeli wobec nieletniego, który dopuścił się czynu karalnego, ale w chwili orzekania ukończył już 18 lat, zachodziły podstawy do orzeczenia o umieszczeniu w zakładzie poprawczym, sąd rodzinny mógł wymierzyć karę, jeżeli uznał, że zastosowanie środka poprawczego byłoby niecelowe. Przepis ten został uchylony na mocy ustawy z dnia 30 sierpnia 2013 r. o zmianie ustawy o postępowaniu w sprawach nieletnich oraz niektórych innych ustaw (Dz.U. z 2013 r., poz. 1165). Uchylenie tego unormowania nastąpiło z dniem 2 stycznia $2014 \mathrm{r}$.

Skreślenie art. 13 u.p.n. należy uznać za słuszne posunięcie. Niezależnie już od tego, że wprowadzał on możliwość wymierzenia kary z mocą wsteczną — za czyny popełnione w okresie nieletniości i to już od 13 roku życia, to stwarzał on też stan niepewności, czy w sytuacji jego zastosowania możliwe było również orzeczenie środków 


\section{Możliwości zastosowania środków zabezpieczających wobec nieletnich sprawców czynów karalnych po nowelizacji k.k. z dnia 20 lutego 2015 r.}

Bardzo poważne zmiany $\mathrm{w}$ treści uregulowań kodeksu karnego zostały wprowadzone $\mathrm{w}$ drodze nowelizacji tego aktu prawnego $\mathrm{z}$ dnia 20 lutego 2015 r. ${ }^{19}$ Przekształcenia te nie ominęły rozdziału X k.k. poświęconego regulacji środków zabezpieczających — przeciwnie: ta część kodeksu karnego uległa chyba najpoważniejszym zmianom spośród wszystkich unormowań tego aktu prawnego. Pomimo gruntownego przebudowania przepisów poświęconych regulacji środków zabezpieczających projektodawcy nie wprowadzili tam unormowań, które rozstrzygałyby szereg wątpliwości dotyczących odnoszenia ogólnych zasad odpowiedzialności karnej do orzekania środków zabezpieczających. Można by tu wymienić m.in. kwestię stosowania reguł intertemporalnych, zasad odpowiedzialności za czyny popełnione poza granicami kraju, odnoszenie dyrektyw wymiaru kary do środków zabezpieczających czy zakres wdrażania środków zabezpieczających do osób dopuszczających się czynów karalnych w poszczególnych formach stadialnych i zjawiskowych. Do tej sfery nieuregulowanych zagadnień należy również w dalszym ciagu niejasno określona kwestia dopuszczalności i celowości orzekania przez sądy środków zabezpieczających względem nieletnich sprawców czynów karalnych.

Na wstępie zauważyć należy, że uchylona została w wyniku nowelizacji treść art. 93 k.k., która przewidywała zasadę niezbędności (ostateczności) stosowania izolacyjno-leczniczych środków zabezpieczających oraz leczenia ambulatoryjnego. Zasada ta została jednak utrzymana, a nawet rozszerzona także na wolnościowe środki zabezpieczające. W treści nowe-

zabezpieczających. W przeciwieństwie do regulacji z art. 94 u.p.n. niewątpliwie orzeczenie wydane na podstawie art. 13 u.p.n. stanowiło wyrok skazujący. Różniło się ono jednak istotnie od sytuacji skazania osoby dorosłej czy nawet nieletniego na podstawie art. $10 \S 2$ k.k. O uzasadnieniu skreślenia art. 13 u.p.n. pisze szerzej V. Konarska-Wrzosek, Prawny system postępowania..., s. $136-137$.

19 Ustawa o zmianie ustawy Kodeks karny oraz niektórych innych ustaw z dnia 20 lutego 2015 r., Dz.U. z 2015 r., poz. 396. Przepisy wprowadzone w drodze tej nowelizacji weszły w życie w dniu 1 lipca 2015 r. 
go art. 93b $§ 1$ k.k. stwierdzono bowiem, że „Sąd może orzec środek zabezpieczający, gdy to jest konieczne aby zapobiec ponownemu popełnieniu przez sprawcę czynu zabronionego, a inne środki prawne określone w tym kodeksie lub orzeczone na podstawie innych ustaw nie są wystarczające [...]". Tym samym w dalszym ciagu zastosowanie środków zabezpieczających wobec nieletnich sprawców czynów karalnych napotyka barierę podwójnej wyjątkowości: po pierwsze, już samo pociągnięcie do odpowiedzialności karnej nieletnich na podstawie art. $10 \S 2 \mathrm{k} . \mathrm{k}$. ma charakter wyjątkowy, a po drugie równie wyjątkowe może być orzekanie wobec nich wszystkich przewidzianych prawnie (także pozakodeksowych) środków zabezpieczających — zarówno izolacyjnych, jak i nieizolacyjnych.

Spośród zmian nowelizacyjnych mających znaczenie dla omawianego tu zagadnienia należy wymienić zniesienie instytucji przewidzianej w art. 95 k.k. (tj. środek izolacyjno-leczniczy realizowany w trakcie odbywania kary pozbawienia wolności przez sprawców o ograniczonej poczytalności) i zastąpienie jej środkiem zabezpieczającym zawartym $\mathrm{w}$ treści art. $93 \mathrm{~g} \S 2 \mathrm{k} . \mathrm{k}$. Zgodnie z tym nowym uregulowaniem przestępca, który w chwili czynu znajdował się w stanie poczytalności ograniczonej w stopniu znacznym, jeżeli został skazany na karę pozbawienia wolności bez warunkowego jej zawieszenia, karę 25 lat pozbawienia wolności lub karę dożywotniego pozbawienia wolności, może zostać skierowany przez sąd tytułem środka zabezpieczającego do zakładu psychiatrycznego, jeżeli sąd stwierdzi, że istnieje wysokie prawdopodobieństwo, że sprawca taki popełni czyn zabroniony o znacznej szkodliwości społecznej w związku z chorobą psychiczną lub upośledzeniem umysłowym. Zgodnie z treścią uzupełniającego ten przepis art. 202a § 1 k.k.w., pobyt w zakładzie psychiatrycznym orzeczony wobec takiej osoby następuje przed wykonaniem kary pozbawienia wolności, podczas przerwy w jej wykonaniu lub po jej wykonaniu. W treści art. 202a $§ 2$ k.k.w. podkreślono, że sąd zalicza na poczet kary okres pobytu skazanego w zakładzie psychiatrycznym.

Gdyby ta nowa, przedstawiona tu regulacja, miała znaleźć zastosowanie do piętnasto- i szesnastolatków skazywanych na podstawie art. 10 $\S 2$ k.k., musiałaby się ona spotkać z poważnymi uwagami krytycznymi. Po pierwsze już sama możliwość orzeczenia wobec nieletnich kary 25 lat pozbawienia wolności wydaje się pozostawać w sprzeczności z zasadą 
kary nie przekraczającej stopnia winy ${ }^{20}$. Jakkolwiek nie ulega obecnie wątpliwości możliwość orzeczenia wobec nieletnich skazywanych na podstawie art. $10 \S 2$ k.k. tej kary za najpoważniejsze zbrodnie, to jednak taka możliwość powinna zostać zniesiona. Pogodzenie tej kary z zasadą wychowawczego racjonalizowania kar orzekanych nieletnim, określoną w treści art. $54 \S 1$ k.k., w oczywisty sposób nie jest możliwe. Kara 25 lat pozbawienia wolności nie może odgrywać żadnej roli wychowawczej jest to $\mathrm{w}$ istocie zakamuflowany środek ochronny mający na celu przede wszystkim długotrwałą izolację społeczną niebezpiecznych i wyjątkowo zdemoralizowanych przestępców ${ }^{21}$. Dopuszczalność jej zastosowania wobec nie w pełni sprawnych umysłowo, nieletnich przestępców razi swoją surowością na tle analogicznych unormowań przewidzianych w ustawodawstwach innych państw europejskich ${ }^{22}$. Jakby mało było orzeczenia tej

20 Zdarza się, że nie tylko prawnicy, ale również lekarze psychiatrzy są zdania, że wprowadzenie odpowiedzialności karnej nieletnich narusza zasadę odpowiedzialności karnej na zasadzie winy, ale niekiedy - w ujęciu zwolenników tego poglądu — jest to konieczne ze względu na prymat ochrony społecznej wobec niewielkiej możliwości osiagnnięcia tego celu za pomocą środków wychowawczych i poprawczych stosowanych przez sądy rodzinne. Zob. J. Przybysz, Psychiatria sqdowa. Opiniowanie w procesie karnym, Toruń 2003, s. 62.

21 Całkowitą słuszność miał A. Marek stwierdzając, że stosowanie wobec nieletnich przestępców kary 25 lat pozbawienia wolności nie uwzględnia ich umniejszonego stopnia winy, a wymiar tej kary odbiega od standardów światowych oscylujących wokół maksymalnej granicy 10-15 lat pozbawienia wolności. Zob. A. Marek, Uwagi o reformie prawa dotyczacego nieletnich, „Archiwum Kryminologii”, t. XXIX-XXX, 2007-2008, s. 388; por. też V. Konarska-Wrzosek, Prawny system postępowania ..., s. 132-133.

${ }^{22}$ W Niemczech, które do niedawna mogły stanowić wręcz wzór państwa realizującego racjonalną i skuteczną politykę karną wobec przestępców nieletnich, kara pozbawienia wolności orzeczona względem takich sprawców ograniczona była w wymiarze od 8 miesięcy do 5 lat. Wyjątkowo, w przypadku najcięższych przestępstw dopuszczalne było orzeczenie kary do 10 lat pozbawienia wolności (Zob. H.J. Albrecht, Ewolucja prawa karnego nieletnich w Niemczech, [w:] Problemy reformy postepowania w sprawach nieletnich, red. T. Bojarski, Lublin 2008, s. 190).

Z kolei obowiązująca w Hiszpanii od 12 stycznia 2000 r. ustawa o odpowiedzialności karnej nieletnich przewiduje, że nieletni w wieku od 14 do 18 lat mogą ostać umieszczeni w tzw. reżimie zamkniętym (odpowiednik kary pozbawienia wolności dla dorosłych) w określonych wypadkach na okres 3 bądź 5, ewentualnie 6 lat. Tylko w razie wielości popełnionych czynów karalnych, wobec osób, które ukończyły szesnasty rok życia umieszczenie w reżimie zamkniętym, może trwać do 10 lat (Zob. B. Kunicka-Mi- 
niezwykle surowej kary wobec nieletnich, to dodatkowo na mocy nowych uregulowań mogą być oni, po zakończeniu odbywania kary pozbawienia wolności, umieszczeni w zakładzie psychiatrycznym na czas z góry nieokreślony. Uwzględniając nowoczesne, humanitarne rozwiązania przewidziane w omawianej kwestii w innych krajach zachodniej Europy jeżeli w ogóle utrzymywać karalność osób nieletnich — to należałoby przynajmniej ograniczyć maksymalna, górną granicę kary wymierzanej takim osobom do 10, ewentualnie 15 lat pozbawienia wolności. W obecnym stanie prawnym, na gruncie regulacji zawartych w art. $93 \mathrm{~g} \S 2 \mathrm{k} . \mathrm{k}$. oraz art. 202a k.k.w., regułą powinno być umieszczanie nieletnich sprawców przestępstw o poczytalności znacznie ograniczonej w zakładzie psychiatrycznym przed odbyciem kary pozbawienia wolności, a następnie zaliczenie okresu internacji na poczet wykonywanej później kary.

$\mathrm{W}$ dalszym ciagu — obecnie na podstawie art. 93g $§ 3 \mathrm{k} . \mathrm{k}$. w zW. z art. 93d $\S 5$ k.k. — pozostaje możliwość skierowania nieletnich przestępców skazanych na podstawie art. $10 \S 2$ k.k. do zakładu psychiatrycznego po odbyciu kary pozbawienia wolności lub kary 25 lat pozbawienia wolności, jeżeli dopuścili się oni przestępstwa określonego w treści art. 93c pkt 3 k.k. w związku z zaburzeniem preferencji seksualnych. Odnieść tu należy wspomniane już wcześniej argumenty przeciwko analogicznej regulacji, która istniała w kodeksie karnym w okresie obowiązywania art. 95a oraz podniesione wyżej zastrzeżenia w zakresie realizowanego postpenalnie środka zabezpieczającego względem nieletnich o poczytalności ograniczonej.

Jako argument negujący możliwość stosowania wobec nieletnich izolacyjnych środków zabezpieczających o charakterze postpenalnym można by także potraktować wypracowanie i opublikowanie Europejskich reguł wykonywania sankcji i środków orzeczonych wobec nielet-

chalska, Odpowiedzialność karna nieletnich w Hiszpanii, [w:] Problemy reformy postępowania..., s. 226, 233).

$\mathrm{Na}$ tle państw europejskich wyróżnia się pod względem surowości kar orzekanych wobec nieletnich prawo francuskie. Obowiązujący tam od 1992 r. kodeks karny dopuszcza orzeczenie wobec nieletnich kary 20 lat pozbawienia wolności za najcięższe przestępstwa (Zob. P. Chrzczonowicz, Francuskie prawo karne, [w:] A. Adamski et al., Prawo karne $i$ wymiar sprawiedliwości państw Unii Europejskiej. Wybrane zagadnienia, Toruń 2007, s. 62-63). 
nich sprawców czynów karalnych. Zostały one przyjęte w dniu 5 listopada 2008 r. przez Komitet Ministrów Rady Europy jako forma zalecenia dla kierunków polityki karnej państw członkowskich Rady Europy. Zalecenie to w treści reguły nr 3 nakazuje, aby wszelkie sankcje orzekane wobec nieletnich posiadały charakter oznaczony w czasie, co na pierwszy rzut oka wykluczałoby realizację względem tej grupy sprawców sankcji terminowo nieoznaczonych, a w tym i środków zabezpieczających. Celem Reguł jest przerwanie praktyki realizowania w niektórych krajach, w stosunku do nieletnich, kary dożywotniego pozbawienia wolności oraz długoterminowych środków zabezpieczających, których uzasadnieniem byłaby wyłącznie ochrona społeczeństwa przed nieletnimi sprawcami czynów karalnych, jeżeli sankcje te nie dawałyby takim nieletnim w praktyce żadnej szansy na uzyskanie wolności w rozsądnym terminie. Wskazane Reguły sugerują także, aby w razie konieczności izolacji nieletnich przestępców byli oni umieszczani w instytucjach o możliwie niskim poziomie zabezpieczenia, co również stawia pod znakiem zapytania dopuszczalność realizacji względem nieletnich izolacyjnych środków zabezpieczających. Zasadniczym celem sankcji stosowanych wobec nieletnich przestępców według wskazań tego dokumentu Rady Europy powinna być ich społeczna reintegracja. Nie może natomiast być jedynym uzasadnieniem ich stosowania osiagnięcie celu zabezpieczającego lub ogólnoprewencyjnego ${ }^{23}$.

Wydaje się wszakże, iż postanowienia przywołanego tu dokumentu Komitetu Ministrów Rady Europy nie stoją na przeszkodzie stosowaniu w rodzimym ustawodawstwie środków zabezpieczających w stosunku do nieletnich, pod warunkiem, że środki te będą orzekane i wykonywane zgodnie z celami zakładanymi przez wskazane wytyczne. Tym samym celem tych środków nie może być wyłącznie detencja ochronna. Przepisy

23 F. Dünkel, A. Baechtold, D. van Zyl-Smit, Europejskie reguty wykonywania sankcji i środków orzeczonych wobec nieletnich sprawców czynów karalnych, „Archiwum Kryminologii” 2009, t. XXXI, s. 40-41.

Dodać tu należy, że zawarte w dokumencie Rady Europy zalecenia odnoszą się do wszelkich form pozbawienia wolności nieletnich. Dotyczą one także tych jednostek, które nie osiągnęły wieku odpowiedzialności karnej, a które zostały uznane za przejawiające objawy demoralizacji i poddane izolacji w instytucjach, do których mogą trafić także nieletni sprawcy przestępstw (ibidem, s. 18). 
krajowe muszą też określać warunki, zgodnie z którymi możliwe będzie chociażby warunkowe opuszczenie przez nieletniego placówki internacyjno-zabezpieczającej w rozsądnym terminie, pozostające w zgodności z zasadą humanitarnego traktowania nieletnich i młodocianych przestępców. Poza tym realizacji środków zabezpieczających wobec nieletnich, zwłaszcza środków o charakterze postpenalnym, musi zarazem towarzyszyć reforma (złagodzenie) górnych granic ustawowego wymiaru kar najsurowszych. W tym sensie dużo bardziej zgodne ze wskazanymi Regułami byłoby stosowanie wobec nieletnich sprawców najpoważniejszych przestępstw kombinacji kary pozbawienia wolności nie przekraczającej lat 15 i postpenalnego środka izolacyjno-leczniczego, niż orzekanej obecnie w niektórych wypadkach kary 25 lat pozbawienia wolności.

Nową kategorię sprawców, wobec których możliwe jest po nowelizacji lutowej orzeczenie środków zabezpieczających, stanowią określeni w art. 93c pkt 4 k.k. przestępcy skazani na karę pozbawienia wolności bez warunkowego zawieszenia jej wykonania za umyślne przestępstwo określone w rozdziale XIX, XXIII, XXV lub XXVI k.k., popełnione w związku z zaburzeniem osobowości o takim charakterze lub nasileniu, że zachodzi co najmniej wysokie prawdopodobieństwo popełnienia czynu zabronionego z użyciem przemocy lub groźbą jej użycia. W tym przypadku należy stwierdzić, że rozpoznanie wystąpienia zaburzeń osobowości u osób, które nie ukończyły 16 roku życia, jest bardzo trudne ${ }^{24}$. U osób nieletnich proces kształtowania się osobowości nie został bowiem zakończony, stąd też to, co u osoby dorosłej może być uznawane za symptom zaburzenia osobowości, u nieletniego będzie często wyrazem nieukończonych, zachodzących jeszcze w niej naturalnych przemian. Wydaje się zatem, że środki zabezpieczające przewidziane w stosunku do kategorii dorosłych przestępców zaburzonych osobowościowo nie powinny znaleźć zastosowania do przestępców nieletnich. Chodziłoby tu wyłącznie o tzw. środki wolnościowe, tj. terapię, terapię uzależnień oraz elektroniczną kontrolę miejsca pobytu, bowiem względem przestępców wykazujących zaburzenia osobowości nowe przepisy kodeksu karnego nie przewidują zastosowania środków zabezpieczających o charakterze

24 B. Pastwa-Wojciechowska, Wybrane problemy orzecznictwa sqdowo-psychologicznego w sprawach karnych, Gdańsk 2000, s. 35, 38. 
izolacyjno-leczniczym. Wbrew pozorom wolnościowe środki zabezpieczające stosowane względem nieletnich, poczytalnych przestępców wcale nie muszą okazać się bardziej skuteczne i mniej uciążliwe niż instytucje tego rodzaju o charakterze izolacyjnym. W pierwszym rzędzie trzeba zwrócić uwagę na to, że nieizolacyjne środki zabezpieczające nie będą przeciwdziałały tym czynnikom kryminogennym, które w przypadku nieletnich przestępców z reguły mają decydujące znaczenie dla społecznego ich wykolejenia - a więc oddziaływaniu patologicznego środowiska, w którym nieletni dorasta i podlega nieprawidłowemu procesowi wychowawczemu ${ }^{25}$. Rozwiązanie, na gruncie którego piętnasto- i szesnastoletni przestępcy mieliby uczęszczać do poradni lecznictwa czy poradni uzależnień, budzi wątpliwości pod względem jego skuteczności ${ }^{26}$. Nieletni ci w dalszym ciaggu będą zazwyczaj przebywali w niekorzystnym dla siebie, kryminogennym środowisku. Jeżeli dodać do tego, że w wypadku niestosowania się przez nich do obowiązków wynikających z nałożenia wolnościowych środków zabezpieczających, które to zachowanie zagrożone jest jako przestępstwo określone w art. 244b $\S 1$ k.k. karą nawet do 2 lat pozbawienia wolności, nieletni mogą trafić do zakładu karnego, to wskazane rozwiązanie przedstawia się nie tylko jako potencjalnie nieskuteczne, ale po prostu jako rozwiązanie złe i szkodliwe. Dodatkowo, jeśli środek zabezpieczający przyjmie postać elektronicznej kontroli miejsca pobytu, to w przypadku przestępców nieletnich w wielu przypadkach noszenie nadajnika (tzw. elektronicznej ,,bransolety”) będzie trwale stygmatyzować takie osoby jako należące do środowiska przestępczego.

25 Należy uwzględnić, że — dla porównania - decyzja o zastosowaniu środków wychowawczych lub poprawczych wiążących się z koniecznością okresowej izolacji społecznej powinna przede wszystkim służyć ochronie nieletnich przed negatywnym wpływem środowiska, w którym przebywają. Zob. E. Filipkowska, op. cit, s. 53.

26 Próby oddziaływania na młodych, zaburzonych osobowościowo przestępców za pomocą terapii, w tym leczenia odwykowego, po odbyciu kary, w warunkach dobrowolnego przyjęcia na siebie tych obowiązków jako formy pomocy postpenitencjarnej były już podejmowane na początku lat sześćdziesiątych ubiegłego wieku. Niestety ich wyniki były stosunkowo słabe, głównie z tego względu, że młodociani przestępcy zaburzeni osobowościowo nie mieli wystarczająco silnej woli długotrwałego, dobrowolnego uczestniczenia w terapii w warunkach wolnościowych. Zob. J. Sikora, Opieka postpenitencjarna nad byłymi więźniami psychopatami, charakteropatami i ciężkimi neurotykami, Warszawa 1964, s. 52, 61, 95. 
Podkreślić w tym miejscu należy, że wymienione w art. 93a § 1 pkt 1-3 k.k. wolnościowe środki zabezpieczające w postaci terapii, terapii uzależnień oraz elektronicznej kontroli miejsca pobytu mogą być stosowane względem nieletnich przestępców odpowiadających na podstawie art. 10 $\S 2$ k.k. także w przypadkach stwierdzenia zaburzeń psychicznych innych niż ustalenie występowania zaburzeń osobowości. Z treści art. 93d § 2 k.k. oraz art. 93d $\S 4 \mathrm{k} . \mathrm{k}$. wynika, że te wolnościowe środki zabezpieczające mogą być stosowane także po zakończeniu pobytu w zakładzie psychiatrycznym przez jednostki niepoczytalne lub o poczytalności ograniczonej, jak i wobec przestępców określonych w treści art. 93c pkt 2-5 k.k. po zakończeniu przez nich odbywania kary pozbawienia wolności.

Z omówionych wyżej względów trudno doszukiwać się dobrych stron rozwiązania polegającego na zniesieniu możliwości umieszczania nieletnich sprawców czynów karalnych w zakładzie leczenia odwykowego, przewidzianego w uchylonym art. 96 k.k. W wyniku ostatnich zmian nowelizacyjnych, zgodnie z treścią art. 93c pkt 5 w zw. z art. 93f $§ 2$ k.k., nieletni przestępcy uzależnieni od alkoholu, środka odurzającego lub innego podobnie działającego środka mogą zostać zobowiązani do stawiennictwa we wskazanej przez sąd placówce leczenia odwykowego w terminach wyznaczonych przez lekarza i poddania się terapii odwykowej. W razie niedopełnienia tych obowiązków osobom poddanym oddziaływaniu tego wolnościowego środka zabezpieczającego grozi — przewidziana w art. $244 \mathrm{~b} \S 1$ k.k. - kara pozbawienia wolności do lat 2. Niełatwo powiedzieć, w jakim stosunku do tej regulacji pozostają przepisy art. 71 pkt 3-5 ustawy o przeciwdziałaniu narkomanii2 ${ }^{27}$. Przepisy te przewidują możliwość umieszczenia w odpowiednim podmiocie leczniczym sprawcy przestępstwa pozostającego w związku z używaniem środka odurzającego lub substancji psychotropowej, jeżeli osoba taka zostanie skazana na karę pozbawienia wolności bez warunkowego zawieszenia jej wykonania. Umieszczenie $\mathrm{w}$ odpowiednim podmiocie leczniczym następuje $\mathrm{w}$ tym wypadku z mocy ustawy przed wykonaniem kary, a sąd rozstrzyga po zakończeniu leczenia, czy orzeczoną karę pozbawienia wolności wykonać. Czasu pobytu w podmiocie leczniczym nie określa się z góry, nie może on

27 Ustawa o przeciwdziałaniu narkomanii z dnia 29 lipca 2005 r., Dz.U. Nr 179, poz. 1485 . 
jednak być dłuższy niż 2 lata ${ }^{28}$. Należy w związku z istnieniem tej dualistycznej regulacji wyrazić pogląd, iż w przypadku przestępców — narkomanów przepisy ustawy o przeciwdziałaniu narkomanii stanowią lex specialis wobec unormowań kodeksowych. Powinny być one realizowane zwłaszcza względem nieletnich, uzależnionych od narkotyków sprawców przestępstw, skazanych na podstawie art. $10 \S 2$ k.k., bowiem w większym stopniu niż analogiczne, wspomniane wyżej uregulowania kodeksowe, dają gwarancję rzeczywistego leczenia detoksykacyjnego oraz możliwości oddziaływań resocjalizacyjnych wobec tych osób, a także umożliwiają odseparowanie nieletnich narkomanów od kryminogennego środowiska.

Nowelizacja kodeksu karnego z dnia 20 lutego 2015 r. wprowadziła także możliwość zastosowania nowego, nieizolacyjnego środka zabezpieczającego względem niepoczytalnych sprawców czynów karalnych. Mowa tu o przewidzianym w art. 39 pkt 2e k.k. nakazie okresowego opuszczenia lokalu zajmowanego wspólnie z pokrzywdzonym, który to nakaz może być orzekany nie tylko jako środek karny, ale także jako środek zabezpieczający na podstawie art. $99 \S 1$ k.k. ${ }^{29}$ Trzeba tu wyraźnie powiedzieć, że przymusowe nakazanie opuszczenia mieszkania nawet wobec dorosłego sprawcy czynu karalnego musi wzbudzać poważne zastrzeżenia. Jest to środek silnie represyjny, godzący w prawo własności, pozbawiający faktycznie miejsca zamieszkania, a jako środek zabezpieczający jest on realizowany wobec osoby niepoczytalnej, którą z reguły będzie człowiek psychicznie chory albo głęboko upośledzony umysłowo.

${ }^{28}$ Na mocy ustawy o zmianie ustawy o przeciwdziałaniu narkomanii oraz niektórych innych ustaw z dn. 24 kwietnia 2015 r., (Dz.U. 2015 poz. 875) nazwa instytucji, w której ma być przeprowadzane leczenie odwykowe została zmieniona z „odpowiedniego zakładu opieki zdrowotnej” na „odpowiedni podmiot leczniczy”.

${ }^{29}$ Co prawda sankcja tego rodzaju została wprowadzona jako środek karny już w 2010 r., jednakże postać środka zabezpieczającego przybrała ona dopiero po nowelizacji kodeksu karnego z dn. 20 lutego 2015 r. Do tego okresu treść art. 99 § 1 k.k. głosiła, że wobec sprawców niepoczytalnych sąd może orzec tytułem środka zabezpieczającego obowiązek oraz zakazy wymienione w art. 39 pkt 2-3 k.k. Ponieważ opuszczenie lokalu zajmowanego wspólnie z pokrzywdzonym następowało w drodze środka karnego przyjmującego formalnie postać nakazu, instytucja ta nie mogła być orzekana tytułem środka zabezpieczającego. Zmiana w tym zakresie nastapiła wraz wejściem w życie nowelizacji lutowej. Treść art. $99 \S 1$ k.k. uległa przekształceniu i obecnie przepis ten głosi, że sąd może w charakterze środka zabezpieczającego zastosować nakaz lub zakazy określone w treści art. 39 pkt 2-3 k.k. 
Tym większe obiekcje nasuwa przyjęcie dopuszczalności tego typu sankcji względem niepoczytalnych, nieletnich sprawców czynów karalnych. Wydaje się, że ustawodawca powinien wyłączyć możliwość orzekania tego typu środka zabezpieczającego w stosunku do piętnasto- i szesnastoletnich przestępców ${ }^{30}$.

Ostatnią kwestią, którą należy rozpatrzyć w ramach omawianego tu zagadnienia, jest dopuszczalność orzekania względem nieletnich sprawców czynów karalnych środka zabezpieczającego w postaci przepadku. Po nowelizacji z dnia 20 lutego 2015 r. przepisy kodeksowe dotyczące przepadku przyjmującego postać środka zabezpieczającego - a więc dotychczasowy art. 100 k.k. oraz część (ostatnie zdanie po przecinku) art. $99 \S 1$ k.k. - zostały usunięte $\mathrm{z}$ rozdziału poświęconego środkom zabezpieczającym. Po połączeniu wskazań tych dwóch artykułów w zakresie odnoszącym się do przepadku przeniesiono je do treści art. 45a zamieszczonego w rozdziale Va k.k. zatytułowanym Przepadek $i$ środki kompensacyjne. Powstaje w związku z tym pytanie, co zmienia owo usytuowanie tej regulacji dla konstrukcji przepadku jako środka zabezpieczającego oraz ewentualnych możliwości jego zastosowania wobec

${ }^{30} \mathrm{Na}$ marginesie prowadzonych tu rozważań można tylko wyrazić poważną wątpliwość, czy treści zawarte w art. $99 \S 1$ i $§ 2$ k.k. w ogóle umożliwiają zastosowanie tego środka zabezpieczającego do jakiegokolwiek sprawcy — także dorosłego. W § 1 tego przepisu ustawodawca wskazał, że tytułem środka zabezpieczającego wobec sprawcy niepoczytalnego sąd może orzec nakaz lub zakazy wymienione w art. 39 pkt 2-3 k.k. Z kolei w $§ 2$ art. 99 k.k. ustawodawca wymienia wyłącznie zakazy, stanowiąc, że „orzeka się je bez określenia czasu ich obowiązywania; sąd uchyla je, gdy ustały przyczyny ich orzeczenia". Z postanowień zamieszczonych w art. $99 \S 2$ k.k. wynikałoby zatem, że nie obejmują one środka zabezpieczającego polegającego na nakazie opuszczenia lokalu mieszkalnego zajmowanego wspólnie z pokrzywdzonym. Tym samym, albo wbrew wyraźnemu postanowieniu wynikającemu z treści art. 99 § 1 k.k., nie przewidziano jednak możliwości orzekania tego nakazu jako środka zabezpieczającego, albo też nakaz ten może być wdrażany jako środek zabezpieczający z tym, że wyłącznie na czas określony, przewidziany dla analogicznego środka karnego, a zarazem sąd nie może uchylić realizacji tego środka zabezpieczającego, mimo że ustały przyczyny jego orzeczenia. Por. J. Majewski, Kodeks karny. Komentarz do zmian 2015, Warszawa 2015, s. 390-391.

Wydaje się, że uregulowania art. $99 \S 1$ i $~ 2$ k.k. w omawianym zakresie są na tyle wadliwe, że wymagają interwencji ustawodawcy. Przyjęcie bowiem, że nakaz opuszczenia lokalu mieszkalnego stosowany wobec osób niepoczytalnych ma być realizowany na zasadach właściwych dla środka karnego, pozostawałby w sprzeczności z sensem i celami realizowania środków zabezpieczających. 
sprawców nieletnich. Przepis ten w obecnym kształcie stanowi, iż: „Sąd może orzec przepadek, jeżeli społeczna szkodliwość czynu jest znikoma, a także w razie warunkowego umorzenia postępowania lub stwierdzenia, że sprawca dopuścił się czynu zabronionego w stanie niepoczytalności, o której mowa w art. 31 § 1 k.k., albo jeżeli zachodzi okoliczność wyłączająca ukaranie sprawcy czynu zabronionego". Odnosząc się do wskazanej kwestii, wypada stwierdzić, że zmiana umiejscowienia tego przepisu poza rozdziałem o środkach zabezpieczających nie zmienia charakteru tej sankcji: w dalszym ciągu przepadek określony w treści art. 45a k.k. pozostaje środkiem zabezpieczającym. Wydaje się natomiast wątpliwe, aby orzekanie względem nieletnich przestępców podlegało ograniczeniom stosowania środków zabezpieczających określonych w art. 93b § 1 k.k. oraz $\mathrm{w}$ art. $93 \mathrm{~b} \S 3-4$ k.k.

\section{Wnioski}

Podsumowując rozważania poświęcone zagadnieniu realizacji środków ochronnych w stosunku do nieletnich sprawców czynów karalnych, można wyróżnić wynikające $\mathrm{z}$ tego wnioski w dwóch płaszczyznach, tj. unormowań obecnie obowiązujących oraz w sferze uregulowań, które powinny powstać w przyszłości.

Na gruncie istniejącej regulacji prawnej, zawartej w k.k. z 1997 r., której postanowienia nie rozstrzygają omawianej tu kwestii w sposób wyraźny, należy się opowiedzieć za interpretacją dopuszczającą możliwość wdrażania środków zabezpieczających w stosunku do nieletnich odpowiadających za czyny karalne na podstawie art. $10 \S 2$ tego aktu prawnego. Nie wydaje się przy tym wszakże, aby możliwe było na gruncie wykładni systemowej oraz celowościowej realizowanie w stosunku do nieletnich wszystkich form i postaci środków zabezpieczających określonych $\mathrm{w}$ rozdziale $\mathrm{X}$ k.k. — takie rozwiązanie pozostawałoby bowiem zapewne w sprzeczności np. z zasadą humanitaryzmu zawartą w art. 3 k.k.

Oceniając celowość wdrażania poszczególnych, przewidzianych obecnie w kodeksie karnym środków zabezpieczających wobec nieletnich przestępców odpowiadających jak dorośli, można wyrazić pogląd, iż uzasadnione jest stosowanie wobec tej kategorii sprawców internacji psy- 
chiatrycznej przewidzianej w art. 93g § 1 k.k., w razie stwierdzenia ich niepoczytalności w chwili popełnienia czynu zabronionego. Nie widać też przeszkód ani przeciwwskazań w nakładaniu na nieletnich sprawców zakazów przewidzianych w art. $99 \S 1$ k.k. oraz przepadku określonego w treści art. 45a k.k. Celowe natomiast wydaje się znowelizowanie art. 99 § 1 k.k. poprzez wprowadzenie w nim zastrzeżenia, że nakaz opuszczenia lokalu przyjmujący postać środka zabezpieczającego nie dotyczy nieletnich niepoczytalnych sprawców czynów karalnych odpowiadających na podstawie art. $10 \S 2$ k.k. Prawo karne nie powinno się stać narzędziem faktycznego pozbawiania nieletnich domu rodzinnego, nawet jeżeli są to osoby głęboko zdemoralizowane i wyrządzające krzywdę swoim najbliższym.

Celowa wydaje się natomiast realizacja wobec tej kategorii sprawców czynów karalnych leczniczego środka zabezpieczającego, przewidzianego w art. 71 pkt 3-5 Ustawy o przeciwdziałaniu narkomanii. W dalszym ciagu brak jest wszakże precyzyjnego ustalenia stosunku tych przepisów wobec treści kodeksowego środka zabezpieczającego, przewidującego przymusowe leczenie osób skazanych za przestępstwo popełnione w związku z uzależnieniem od alkoholu, środka odurzającego lub innego podobnie działającego środka (art. 93c pkt $5 \mathrm{w} \mathrm{zW}$. z art. $93 \mathrm{f}$ $\S 2$ k.k.). Wydaje się, że w tych wypadkach, w których będzie chodziło o nieletnich narkomanów skazywanych na podstawie art. $10 \S 2$ k.k., sądy powinny raczej stosować leczenie stacjonarne przewidziane w ustawie o przeciwdziałaniu narkomanii — powinno to lepiej służyć przerwaniu związków z kryminogennym otoczeniem nieletniego oraz zapewnić rzeczywiste, nieprzerwane leczenie detoksykacyjne takich osób.

Z dużą ostrożnością z kolei powinny sądy rozważać orzekanie wobec nieletnich sprawców przestępstw przewidzianych w obecnych uregulowaniach rozdziału X k.k. postpenalnych środków zabezpieczających. Dotyczy to zwłaszcza tych przypadków, w których sąd zdecydowałby się na wymierzenie nieletniemu przestępcy kary 25 lat pozbawienia wolności, bowiem kara ta w zasadzie samodzielnie spełnia cele ochronne stawiane izolacyjnym środkom zabezpieczającym, toteż uzupełnienie jej dodatkowo środkiem zabezpieczającym, realizowanym po zakończeniu tej kary, byłoby niecelowe w stosunku do tego typu przestępców.

W przypadku środka zabezpieczającego określonego w treści art. $93 \mathrm{~g} \S 2$ k.k., a więc dotyczącego sprawców o poczytalności ograni- 
czonej, jeżeli jego adresatem byłaby osoba nieletnia, należałoby postulować, aby sądy orzekały realizację tego typu środka przed wykonaniem wobec osoby skazanej kary pozbawienia wolności.

Podkreślić należy, że orzekanie izolacyjno-leczniczego środka zabezpieczającego, przewidzianego w treści art. 93g $\S 3$ k.k., w stosunku do nieletniego zaburzonego seksualnie oraz środków wolnościowych określonych w art. 93a $\S 1$ pkt 1-3 k.k. względem nieletniego przestępcy wykazującego objawy zaburzeń osobowości, może się okazać niemożliwe, ponieważ zdiagnozowanie tego typu zaburzeń na tak wczesnym etapie rozwoju jak 15 czy 16 rok życia jest poważnie utrudnione. Ponadto środki wolnościowe w postaci terapii zaburzeń osobowości mogą się okazać nieskuteczne w przypadku nieletnich i młodocianych sprawców przestępstw, zaś dozór elektroniczny w wielu przypadkach tej kategorii osób będzie czynnikiem trwale, negatywnie je stygmatyzującym.

$\mathrm{Na}$ podstawie sformułowanych tu omówień nasuwa się wniosek, iż możliwości wdrażania środków zabezpieczających wobec nieletnich sprawców czynów karalnych, odpowiadających na podstawie art. 10 $\S 2$ k.k., powinny być w istotnym stopniu zróżnicowane. Chociaż celem tych środków nie jest, jak wiadomo, przysporzenie dolegliwości sprawcy (także nieletniemu) — i w tym zakresie środki ochronne różnią się od kar i środków karnych — to zasadniczego celu środków zabezpieczających nie stanowi także realizacja interesu osoby nieletniej. Ten czynnik może jeszcze w pewnym stopniu jest uwzględniany w przypadku internacji sprawcy niepoczytalnego, ponieważ chodzi o jednostkę chora psychicznie — pacjenta zamkniętego zakładu psychiatrycznego. $\mathrm{Na}$ tym polega zasadnicza różnica pomiędzy tą kategorią sankcji prawa karnego a środkami wychowawczymi, leczniczymi i poprawczymi zawartymi w ustawie o postępowaniu w sprawach nieletnich. Realizacja instytucji zawartych w unormowaniach u.p.n. koncentruje się bowiem właśnie przede wszystkim na uwzględnieniu dobra osób nieletnich, natomiast głównym celem zastosowania środków zabezpieczających zgodnie z ich nazwą - jest ochrona społeczeństwa przed powtórnym popełnieniem czynu karalnego przez jednostkę wykazującą chroniczne predyspozycje do naruszania norm prawa karnego. Takie predyspozycje w przypadku sprawców nieletnich nie mogą mieć z reguły w pełni już ukształtowanego i utrwalonego charakteru. Trzeba też pamiętać, że do- 
legliwość niektórych środków ochronnych w niewielkim tylko zakresie ustępuje pewnym (zwłaszcza izolacyjnym) formom kary. Z tych powodów uzasadniony wydaje się przedstawiony tu postulat dopuszczalności stosowania obecnie tylko niektórych postaci środków zabezpieczających względem nieletnich sprawców czynów zabronionych w ustawie karnej. Reguły orzekania środków zabezpieczających powinny wszakże podlegać w takich przypadkach szczegółowej reglamentacji i być bardziej precyzyjnie ujęte, niż ma to miejsce obecnie.

Jeżeli chodzi o nieletnich, którzy dopuścili się czynów karalnych, a zastosowanie do nich znajdują na mocy decyzji sądu rodzinnego wyłącznie przepisy u.p.n, to wydaje się, że w obecnym stanie prawnym ustawa ta wyłącza stosowanie do nieletnich nie podlegających odpowiedzialności karnej środków zabezpieczających - praktykowane przecież do 1983 r., tj. do momentu wejścia w życie ustawy o postępowaniu w sprawach nieletnich. Ustawa ta wprowadziła bowiem złożony, niemal analogiczny do środków ochronnych przewidzianych w kodeksie karnym, system środków wychowawczych, wychowawczo-leczniczych i poprawczych. Co prawda Sąd Najwyższy dopuścił w swoim orzecznictwie, już pod rządami u.p.n., realizację względem nieletnich sprawców przestępstw środka zabezpieczającego w postaci przepadku z art. 100 k.k. (obecnie art. 45a k.k.), wydaje się jednak, że było to następstwem nazbyt zawężonego zakresu instytucji przepadku przewidzianej w treści ustawy o nieletnich jako środka wychowawczego. Jak wiadomo, w dalszym ciągu treść tego środka wychowawczego ogranicza się wyłącznie do pozbawienia nieletniego rzeczy uzyskanych w związku z popełnieniem czynu karalnego. Wyciagając $\mathrm{z}$ tego faktu konsekwencje, uzasadnione byłoby rozszerzenie zakresu przedmiotów i korzyści, które ulegałyby przepadkowi w ramach orzekanego przez sąd rodzinny środka wychowawczego (zwłaszcza o narzędzia przestępstwa), dzięki czemu sąd ten nie musiałby uciekać się do stosowania przepadku tytułem środka zabezpieczającego, posiłkując się przepisami kodeksu karnego.

Ogólnie rzecz biorąc, w zakresie postulatów de lege ferenda należy poprzeć te wszystkie projekty zmian w regulacjach prawnych, które: po pierwsze - ograniczają do koniecznego minimum odpowiedzialność karną nieletnich, a nawet głoszą konieczność całkowitego zniesienia oddziaływania za pomocą kar kryminalnych w stosunku do tej kategorii 
sprawców przestępstw oraz po drugie - w razie utrzymania karalności nieletnich — wyrażają potrzebę podniesienia zasadniczej granicy wieku odpowiedzialności karnej nieletnich do 18 roku życia. Wydaje się, że środki zabezpieczające powinny w przyszłości znajdować zastosowanie wyłącznie w stosunku do dorosłych sprawców czynów karalnych. Należy postulować, aby do momentu uzyskania pełnoletniości względem przestępców — dzieci z zaburzeniami psychicznymi, osobowościowymi, seksualnymi oraz wykazujących objawy uzależnienia do alkoholu lub narkotyków, stosowane były wyłącznie środki wychowawcze, wychowawczo-lecznicze lub poprawcze przewidziane w ustawie o postępowaniu w sprawach nieletnich.

\section{Admissibility of precautionary measures against juvenile criminals Part II}

\section{Summary}

This article discusses the admissibility of precautionary measures against juvenile criminals. It refers to both juvenile offenders charged as adults pursuant to Art. $10 \S 2$ of the Criminal Code and 15-16-year-old offenders charged pursuant to the provisions of the Procedures in Legal Actions against Juveniles Act of 1982. The article presents the legal status concerning this issue in the period from 1997 to 2015 and relevant changes in the legal regulations concerning precautionary measures introduced by the amendment of the Criminal Code of 20th February 2015.

A thesis formulated in the paper discussed here is that only one type of precautionary measure, which is confiscation, may be used against juveniles subject to the regulations of the Procedures in Legal Actions against Juveniles Act. In relation to juveniles charged under the Criminal Code only the precautionary measures which do not interfere with the provisions of Article 3 of the Criminal Code providing for the rule of humanitarian use of criminal penalties should be implemented. It refers mainly to these forms of isolation precautionary measures which would apply to juvenile criminals after serving imprisonment.

Keywords: preventive measures, criminal liability of young offenders, juvenile delinquents, educational and corrective measures, youth detention centre. 